\title{
Mellanby on the Decline of Science
}

by our Special Correspondent

\section{Canterbury, August 24}

AN attack on the organization of research, every bit as sweeping as was promised in the pre-meeting publicity, was delivered by Professor Kenneth Mellanby, Director of Monks Wood Research Station, at last week's British Association meeting in Canterbury. Before the conference met Professor Mellanby promised to review the changes made since 1945 to improve research efficiency, to illustrate how they have almost all been counter-productive and to provide a solution. And he did just that.

Up to 1939, Professor Mellanby said, Britain received a good return from the money spent on research. Now the return was a poor one. The formation of research groups into rigidly organized teams, overstaffing of laboratories, the use of highly trained technicians and the appointment of the best scientists as administrative heads have all led to a decline. Since 1938, Professor Mellanby said, overall government expenditure has increased twenty times but spending on universities has risen two hundred times and civil research expenditure some four hundred times. But "I do not believe that there has been anything like a commensurate increase in scientific productivity, either in quality or quantity".

Professor Mellanby went on to attack the theory that there has been an information explosion. Many new journals are review journals and "I do not think that the production of original research publications has more than doubled". Quality has not increased either. "I see nothing to suggest anything other than fall-off in the appearance of work of exceptionally high quality in many fields of science".

Why has this decline occurred? "Success in original research depends almost entirely on the worker realizing the significance of his observations" Professor Mellanby said. "In considering research I am therefore an uncompromising elitist-I believe that success and originality depend almost entirely on the efforts of a very few gifted individuals."

Up to 1939 professors and heads of departments produced large numbers of papers, now they may do no original research for years. Departmental staffs are now five times larger and the best scientists are being sterilized by being used as administrators. Rigidly organized teams, expensive recording equipment and the employment of highly skilled technicians are all counterproductive measures as the observations are now made by junior staff and not by the seniors who might realize the significance of what they see. Nowadays senior staff only interpret other people's observations.

The increased number of PhD students is also counter-productive, Professor Mellanby said. Few theses resulted in original publications in spite of the "originality" of work theoretically required to obtain a doctorate, and far too much time was spent supervising $\mathrm{PhD}$ students. Back in the 1930s, Professor Mellanby said, his supervisor, Professor Patrick Buxton, gave him less than $1 \%$ of his time.

The lengthy reorganization of research that has followed last year's report by Lord Rothschild has been planned by people who in the 1930 s would have been doing their most important research and "the new chief scientists appointed by the ministries would probably be better off giving vent to their ideas at a laboratory bench".

"My main worry about the situation is that it is one more unnecessary timeconsuming complication which will produce a further host of unproductive administrators. Already several previously productive scientists are spending hours, which they might have spent in their labs, wrestling with unnecessary and often bogus financial estimates."

So what is the Mellanby solution? His answer is simple. Many of the staff currently in the research councils should be placed in development authorities while original workers should be identified and supported by the research councils in separate laboratories without too much expert assistance. They should be given a three year contract and no security of tenure and allowed to get on with their work. At any time the research worker could withdraw from original research and go to a development authority laboratory where the ideas generated by the research laboratories are exploited.

"The next important change is to cut down the time spent on committee meetings. A total ban on committees for a year would probably be a good first step, though a compromise with a few important ones meeting much less frequently would be more likely to meet with agreement". Committees should also prune themselves dramatically allowing those members with better things to do -in other words their own research - to resign first. And administrators who are scientists should be allowed back to the laboratory bench.

But while Professor Mellanby was planning to reorganize research so that the gifted few can give full time to their ideas, others were presenting the results of their efforts under the present system.

Sir George Porter, Director of the Royal Institution, described how solar energy might meet future power demands, trials of a new drug-'Arvin' - which may prevent the recurrence of thrombosis were revealed, the dangers of computer dating, of tea-drinking while pregnant and of the repeated oil pollution of estuaries were postulated, and work on rheumatism that may lead to improved treatments was outlined.

A symposium on Kent and Europe included a lecture by Dr I. B. Thompson of the University of Southampton which concluded that France had a great deal and Britain rather less to gain from the Channel Tunnel, while an industrial forum on the dangers of instability in our society due to scientific and technological advance failed to get to grips with its subject matter, and Hilary Rose traced the rise and fall of the British Society for Social Responsibility in Science.

All in all the 1,500 who made it to Canterbury had rather better fare than last year, and the association plans to hold a meeting next year in Stirling where the projected symposia on Scotland and North Sea oil should show whether the association is a viable forum for the discussion of matters of public moment.

In spite of the disappointingly small size of this year's meeting the association seemed very much alive and its plans to hold a student conference in January 1974 , tied to the intention of giving both the students, and the school children who make up the British Association Young Scientists, a say in forming the section programmes in future, augur well.

Dr John Kendrew is the president of the association which now has its new constitution. A general committee of 59 members instead of 350 and a council of 22 instead of 75 , aided and abetted by a full time council chairman is now in operation following the Privy Council's approval of the changes earlier this year. 